\title{
River lamprey, Lampetra fluviatilis L., fishery in Latvia - insight into the origin of catch statistics data
}

\author{
Kaspar Abersons, Jānis Birzaks
}

Received - 24 February 2014/Accepted - 09 July 2014. Published online: 30 September 2014; Inland Fisheries Institute in Olsztyn, Poland Citation: Abersons K., Birzaks J. 2014 - River lamprey, Lampetra fluviatilis L., fishery in Latvia - insight into the origin of catch statistics data - Arch. Pol. Fish. 22: 169-179.

\begin{abstract}
Most research to date on the status of the river lamprey, Lampetra fluviatilis L. in Latvia has been done based on catch statistics data. The aim of this study was to explore the present status of the river lamprey fishery in Latvia to improve the understanding of catch statistics data. Currently, river lamprey fishing in Latvia is carried out at 24 fishing grounds located on 17 rivers. The most popular fishing gear is the lamprey fyke net, but lamprey weirs and lamprey trammel nets are also used. The type and design of the fishing gear depends on the parameters of the fishing ground. The catch size is highly variable and is greatly affected by the number of non-resources related circumstances, such as fishing regulations and meteorological factors determining the intensity of lamprey migration during the fishing season and opportunities for fishing during periods of the most intense migration. The fishing effort and the type of fishing gear have also largely changed since the 1960s and 1970s. Therefore, the fluctuation in both the long- and short-term catch data may not correspond to changes in the actual status of the lamprey population.
\end{abstract}

Keywords: catch statistics, fishing gear, fishing management, river lamprey

K. Abersons [ڤ], J. Birzaks

Fish Resources Research Department, Institute of Food Safety

Animal Health and Environment

“BIOR” Daugavgrīvas iela 8, Riga, LV-1048, Latvia

e-mail: kaspars.abersons@bior.gov.lv

\section{Introduction}

The distribution area of the river lamprey, Lampetra fluviatilis L., ranges from the south of Norway to the western part of the Mediterranean. It can be found in coastal waters, estuaries, and accessible rivers along the coast of the Atlantic Ocean and in the Baltic Sea and the North Sea (Ryapolova 1972, Maitland 1980, 2003, Kelly and King 2001, Bartel et al. 2010). There are also some landlocked populations (Maitland 1980, Tuunainen et al. 1980). In Latvia, the river lamprey spawns in almost all rivers and streams flowing into the Baltic Sea and the Gulf of Riga (Eglìte 1961, Ryapolova 1972). In the period from 1990 to 2010, river lamprey adults, or ammocoetes, were found in 50 rivers (Birzaks et al. 2011a). There is no information on the occurrence of landlocked river lamprey populations in Latvia. The river lamprey is the only commercially exploited lamprey species in the Baltic Sea region. Other species are too rare (sea lamprey Petromyzon marinus L.) or too small (brook lamprey Lampetra planeri Bloch) to be fished (Tuunainen et al. 1980, Sjöberg 2011).

Lamprey populations declined during the last century (Kelly and King 2001). To protect the species, river lamprey are included in Council Directive 92/43/EEC (21 May 1992) on the conservation of natural habitats and of wild flora and fauna, as well as in Latvian Cabinet Regulations (No. 396 dated 14 
November 2000) on the "List of Specially Protected Species and Species with Exploitation Limits". The commercial exploitation of the river lamprey in most areas of its occurrence has ceased. River lamprey fisheries of any importance are concentrated in the northern and eastern part of the Baltic Sea (Sjöberg 1982, 2011). Commercial fishing still takes place in Finland, Russia, Latvia, and Estonia (Thiel et al. 2009). According to Masters et al. (2006), the commercial fishing of river lamprey is also carried out on the tidal River Ouse in northeast England. The river lamprey is one of the most important target species in the Latvian inland fishery (Birzaks and Abersons 2011, Sjöberg 2011,) and its importance is higher than in its neighboring countries (Sjöberg 2011).

The biggest annual catches in Latvia were registered in the late 1960s and early 1970s. Nonetheless, during the 1970s, the size of the annual lamprey catch dropped from an exceptionally high $410 \mathrm{t}$ in 1971, to only $8 \mathrm{t}$ in 1980 . During the 1980s, the annual lamprey catch began to increase. Judging from the catch data, it can be concluded that river lamprey resources have currently recovered from their decline and are now stable. However, the annual catch over the last decades has been smaller than before the decline and rarely exceeds $100 \mathrm{t}$ (Birzaks and Abersons 2011, Birzaks et al. 2011b).

In much of the previous research, catch data was recognized as the most suitable source of information for the evaluation of river lamprey resources in Latvia (Eglìte 1961, Eglìte 1975, Ryapolova 1962, Birzaks and Abersons 2011). Nonetheless, there is little attention paid to the fact that the annual catch size can also be greatly influenced by non-resources related circumstances (meteorological factors, the evolution of fishing gears, changes in fishing regulations, etc.). A disadvantage of the simplified approach to catch data is also illustrated by the prediction of a further increase in the lamprey fishery (Eglite 1975), which was made shortly before a severe fall in the annual catch.
The aim of this research is to survey the present status of the river lamprey fishery in the rivers of Latvia in order to gain a better understanding of catch statistics data. In this paper, the design and use of fishing gear at different fishing grounds and the circumstances influencing the size of the catch are studied. This paper also provides a short description of river lamprey fishery management in Latvia.

\section{Material and methods}

The study area includes 24 river lamprey fishing grounds on 17 Latvian rivers. Four of these rivers flow into the Baltic Sea's main basin (ICES subdivision 28), one river into the Irbe Strait, and twelve rivers into the Gulf of Riga (ICES subdivision 28-1) (Fig. 1).

Data on lamprey fishing gear and the fishing process was collected by interviewing fishers from all fishing grounds. The interviews were based on a questionnaire that included questions about the type, design, and use of fishing gear and a request to identify the most important factors causing increases

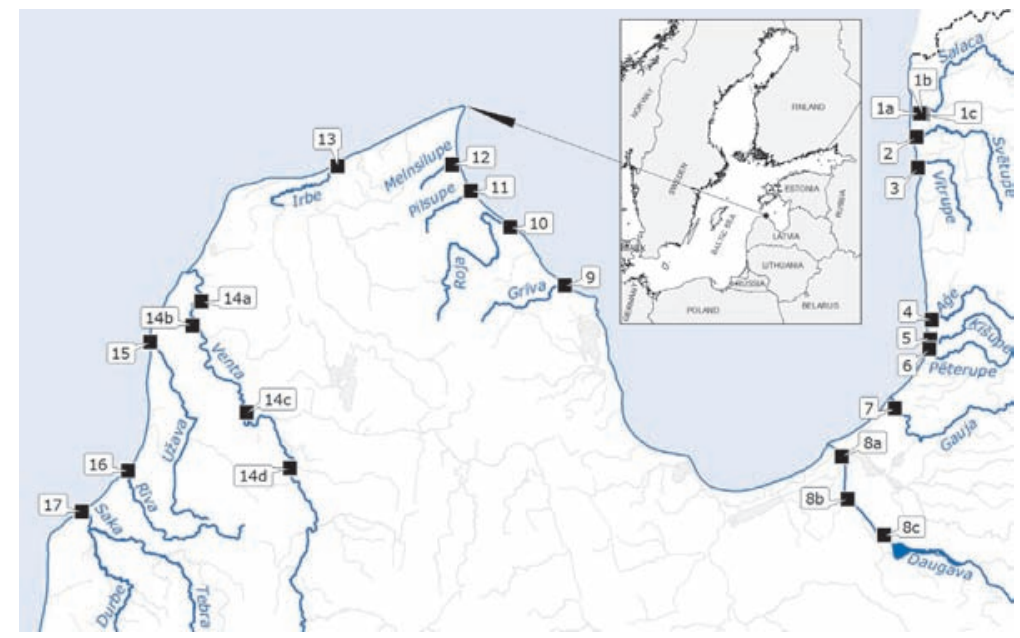

Figure 1. Location of river lamprey L. fluviatilis fishing grounds in Latvia. 1a Salaca River (weir No. 1); 1 b - Salaca River (weir No. 2); 1c - Salaca River (weir No. 3); 2 - Svētupe River; 3 - Vitrupe River; 4 - Ağe River; 5 - Ķīšupe River; 6 Pēterupe River; 7 - Gauja River; 8a - Daugava River (Freeport of Riga); 8b Daugava River (center of the city of Riga); 8c - Daugava River (impact zone of the Riga HPS); 9 - Grīva River; 10 - Roja River; 11 - Pilsupe River; 12 - Melnsilupe River; 13 - Irbe River; 14a - Venta River (Pasiekste); 14b - Venta River (Mērnieki); 14c - Venta River (Zlēkas); 14d - Venta River (Kuldīga); 15 - Užava River; 16 - Rīva River; 17 - Saka River. 
Table 1

Characteristics of river lamprey L. fluviatilis fishing grounds

\begin{tabular}{|c|c|c|c|c|c|}
\hline No. & River & Distance from the sea $(\mathrm{km})$ & Depth (m) & Width (m) & Lamprey fishing gear limit \\
\hline $1 \mathrm{a}$ & Salaca & 1.7 & $0.5-0.8$ & $\sim 150$ & 80 fyke nets \\
\hline $1 b$ & Salaca & 2.65 & $<0.5$ & $\sim 75$ & 30 fyke nets \\
\hline $1 \mathrm{c}$ & Salaca & 2.8 & $<0.5$ & $\sim 75$ & 25 fyke nets \\
\hline 2 & Svētupe & $<5$ & $<0.5$ & $<10$ & 1 fyke net \\
\hline 3 & Vitrupe & $<5$ & Up to 3 & $\sim 15$ & 2 fyke nets \\
\hline 4 & Aǵe & $<5$ & $\sim 3$ & $8-15$ & 2 fyke nets \\
\hline 5 & Ķ̧̄̄̌supe & $<5$ & $\sim 1$ & $<10$ & 1 fyke net \\
\hline 6 & Pēterupe & $<5$ & $\sim 1$ & $<10$ & 1 fyke net \\
\hline 7 & Gauja & $<5$ & $1.5-2$ & $70-150$ & 120 fyke nets \\
\hline $8 \mathrm{a}$ & Daugava & $0-10$ & Up to 6 & $>300$ & \multirow{3}{*}{$\begin{array}{l}214 \text { fyke nets and } 27 \text { trammel } \\
\text { nets }\end{array}$} \\
\hline $8 b$ & Daugava & $10-20$ & $6-12$ & $>300$ & \\
\hline $8 c$ & Daugava & $20-30$ & $0.5-3$ & $>300$ & \\
\hline 9 & Grīva & $<5$ & $\sim 0.7$ & $<10$ & 1 fyke net \\
\hline 10 & Roja & $<5$ & $\sim 2$ & $20-30$ & 2 fyke nets \\
\hline 11 & Pilsupe & $<5$ & $\sim 2$ & $<10$ & 1 fyke net \\
\hline 12 & Melnsilupe & $<5$ & $\sim 1.2$ & $\sim 10$ & 1 fyke net \\
\hline 13 & Irbe & $<5$ & $2-3$ & $30-50$ & 14 fyke nets \\
\hline $14 \mathrm{a}$ & Venta & 11 & $4-5$ & $\sim 200$ & 20 fyke nets \\
\hline $14 \mathrm{~b}$ & Venta & 16 & $3-4$ & $\sim 200$ & 21 fyke net \\
\hline $14 \mathrm{c}$ & Venta & 55 & $1-1.5$ & $60-100$ & 3 fyke nets \\
\hline $14 d$ & Venta & 85 & $1-1.2$ & $90-150$ & 12 fyke nets \\
\hline 15 & Užava & $<5$ & $3.5-4$ & $\sim 20$ & 4 fyke nets \\
\hline 16 & Rīva & $<5$ & $1-2$ & $10-15$ & 2 fyke nets \\
\hline 17 & Saka & $<5$ & $4-5$ & $\sim 40$ & 16 fyke nets \\
\hline
\end{tabular}

or decreases in catches. In the fishing grounds located in the Salaca, Svētupe, Vitrupe, Ağe, Pēterupe, Gauja, Daugava, Venta, Užava, Rīva, and Saka rivers, the fishers were visited and interviewed in October 2011. Fishers fishing in the Ķǐšupe, Daugava, Roja, Pilsupe, Melnsilupe, and Irbe rivers were interviewed by telephone in March 2013.

Catch data analysis covers the period from 2000 to 2012. An evaluation of the catch size at each fishing ground and an estimation of the number of fishers and fishing enterprises involved in lamprey fishery was made based on yearly catch statistics data. Catch data collection is described in the management chapter in the results section.

\section{Results}

\section{Fishing grounds}

Currently, river lamprey fishing in Latvia is carried out at 24 fishing grounds on 17 rivers (Fig. 1). The majority of the lamprey fishing grounds are on the lowest parts of rivers less than $5 \mathrm{~km}$ from the sea. The exceptions are the fishing grounds on the Venta and Daugava rivers. On the Venta River, the lamprey fishing grounds are $11 \mathrm{~km}, 16 \mathrm{~km}, 55 \mathrm{~km}$, and $85 \mathrm{~km}$ from the sea. Lamprey fishing on the Daugava River is carried out in all the areas accessible to lampreys extending from the sea to the Riga HPS dam. The 
Table 2

Overview of annual river lamprey L. fluviatilis catch size at different fishing grounds from 2000 to 2012

\begin{tabular}{|c|c|c|c|c|c|c|c|}
\hline \multirow[b]{2}{*}{ No. } & \multirow[b]{2}{*}{ River } & \multicolumn{2}{|c|}{ Smallest catch } & \multicolumn{2}{|c|}{ Biggest catch } & \multirow{2}{*}{$\begin{array}{l}\text { Mean catch } \\
\text { (t) }\end{array}$} & \multirow[b]{2}{*}{ Share $(\%)$} \\
\hline & & Catch (t) & Year & Catch (t) & Year & & \\
\hline $1 \mathrm{a}$ & Salaca & 3.1 & 2001 & 9.3 & 2005 & 6.2 & $3.6-10.4$ \\
\hline $1 b$ & Salaca & 1.4 & 2010 & 10.9 & 2003 & 5.4 & $1.9-9.7$ \\
\hline \multirow[t]{2}{*}{$1 \mathrm{c}$} & Salaca & 3.3 & 2010 & 9.1 & 2004 & 5.3 & $3.0-9.9$ \\
\hline & Salaca total & 8.2 & 2010 & 23.3 & 2005 & 16.9 & $11.2-26.1$ \\
\hline 2 & Svētupe & 0.3 & 2001 & 1.3 & 2011 & 0.8 & $<1$ \\
\hline 3 & Vitrupe & $<0.1$ & 2000 & 1.0 & 2006 & 0.5 & $<1$ \\
\hline 4 & Ağe & $<0.1$ & 2010 & 0.5 & 2008 & 0.3 & $<1$ \\
\hline 5 & Pēterupe & $<0.1$ & 2012 & 0.3 & 2011 & 0.1 & $<1$ \\
\hline 6 & Ķ̧̄̌supe & \multicolumn{6}{|c|}{ Fishing is started in 2013 , catch data are not yet available } \\
\hline 7 & Gauja & 11.0 & 2010 & 34.9 & 2000 & 21.1 & $12.3-31.1$ \\
\hline 8 & Daugava & 9.7 & 2002 & 31.5 & 2012 & 22.4 & $12.3-36.5$ \\
\hline 9 & Grīva & $<0.1$ & 2010 & 0.9 & 2000 & 0.4 & $<1$ \\
\hline 10 & Roja & 0.5 & 2010 & 4.5 & 2000 & 1.7 & $0.7-3.3$ \\
\hline 11 & Pilsupe & $<0.1$ & 2003 & 0.8 & 2012 & 0.3 & $<1$ \\
\hline 12 & Melnsilupe & $<0.1$ & 2007 & 0.2 & 2002 & $<0.1$ & $<1$ \\
\hline 13 & Irbe & 1.5 & 2010 & 4.9 & 2000 & 2.7 & $1.9-4.1$ \\
\hline $14 \mathrm{a}$ & Venta & 2.9 & 2009 & 11.3 & 2000 & 5.6 & $2.9-9.7$ \\
\hline $14 \mathrm{~b}$ & Venta & 2.8 & 2005 & 17.8 & 2000 & 7.5 & $3.1-15.6$ \\
\hline $14 \mathrm{c}$ & Venta & $<0.1$ & 2005 & 3.2 & 2003 & 1.2 & $<1-3.3$ \\
\hline \multirow[t]{2}{*}{$14 d$} & Venta & 0.3 & 2012 & 12.9 & 2007 & 6.3 & $4.0-11.4$ \\
\hline & Venta total & 9.3 & 2005 & 34.7 & 2000 & 20.4 & $10.4-33.4$ \\
\hline 15 & Užava & 0.5 & 2012 & 2.5 & 2003 & 1.3 & $0.6-2.2$ \\
\hline 16 & Rīva & 0.1 & 2001 & 2 & 2006 & 0.8 & $0.1-2.1$ \\
\hline 17 & Saka & 3.3 & 2001 & 13.7 & 2003 & 7.4 & $3.8-12.3$ \\
\hline Total & & 72.8 & 2010 & 136.4 & 2000 & 97.1 & - \\
\hline
\end{tabular}

Daugava River can be divided into three lamprey fishing grounds: the Freeport of Riga (0 to $10 \mathrm{~km}$ from the sea); the center of Riga (10 to $20 \mathrm{~km}$ from the sea); the direct impact zone of the Riga HPS (20-30 $\mathrm{km}$ from the sea). Lamprey fishing on the Salaca River is carried out at three traditional lamprey weir locations, and each of the weirs is considered to be a separate fishing ground. The depth of the river at different fishing grounds ranges from 0.5 to $12 \mathrm{~m}$ and the width of the river ranges from less than $10 \mathrm{~m}$ up to $300 \mathrm{~m}$ (Table 1).

\section{Catch size}

From 2000 to 2012 the total annual catch in Latvia fluctuated from $72.1 \mathrm{t}$ in 2010 to $136.4 \mathrm{t}$ in 2000 . The biggest annual catches were obtained at the fishing grounds located on the largest Latvian rivers - the Gauja, Daugava, Venta, and Salaca (Table 2). In the period studied, the share of each of these rivers in total annual landings exceeded 10\%. A considerable catch was also obtained at the fishing grounds on the Roja, Irbe, Užava, Rīva, and Saka rivers. At other fishing grounds, the annual catch was small, and the share of each did not usually exceed $1 \%$. The 


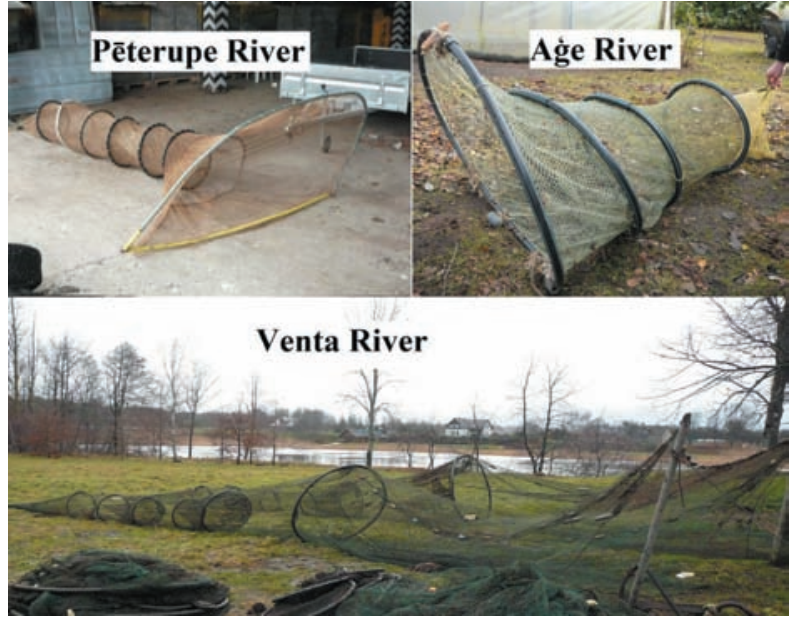

Figure 2. Design of the "regular" lamprey fyke net in some rivers Pēterupe River (fishing ground No. 6); Ağe River (fishing ground No. 4); Venta River (fishing grounds Nos. 14a and 14b).

smallest and biggest annual catches at the majority of the fishing grounds were obtained in different years. This also applies to the fishing grounds located on the same river.

\section{Fishing gear}

The most common type of lamprey fishing gear in Latvia is the "regular" lamprey fyke net. The design and size of the fyke net depends on the parameters (depth, width, and flow velocity) of the fishing ground (Fig. 2). Most of the "regular" lamprey fyke nets are 8 to $12 \mathrm{~m}$ long, $4 \mathrm{~m}$ wide and 1.5 to $3 \mathrm{~m}$ high. They have a square or round opening and a round cod-end. The height of the opening corresponds to the water depth at the fishing ground. The netting of the fyke nets is traditionally made of nylon, but the experimental use of polypropylene has begun in recent years.

Different gear (strongly modified fyke nets, trammel nets, and lamprey weirs) are used in the Daugava, Salaca, and Svētupe Rivers and in the upper (No. 14d) fishing ground on the Venta River. The type and design of the fishing gear in the Daugava River differs according to the distance from the sea. In the lowest reaches (No. 8a), the fyke nets are adapted to a relatively low current speed and a great depth (up to $8 \mathrm{~m}$ ) near the fairway. These fyke nets

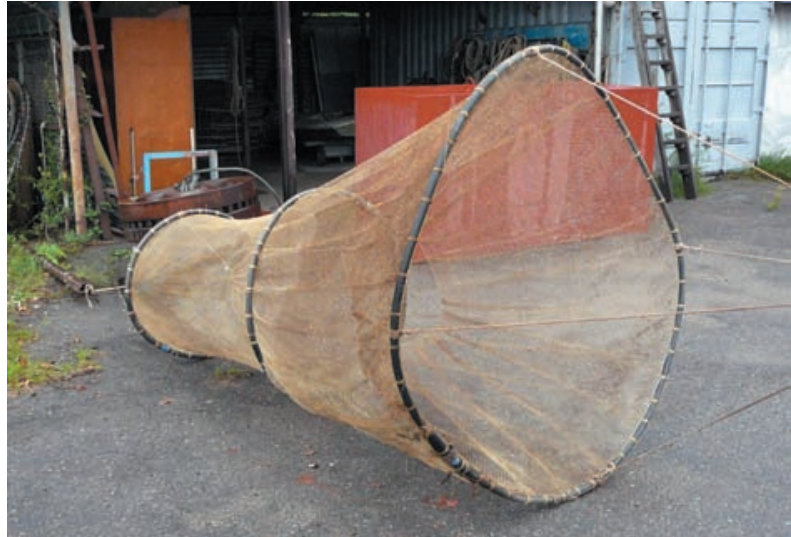

Figure 3. Design of the fyke net in the Daugava River (fishing ground No. $8 b$ ).

are square shaped and up to $12 \mathrm{~m}$ long and have a relatively large ( $4 \mathrm{~m}$ wide and up to $6 \mathrm{~m}$ high) opening. Such fyke nets are usually combined with wings up to $15 \mathrm{~m}$ long. At the fishing grounds located $10-20 \mathrm{~km}$ from the sea (No. $8 \mathrm{~b}$ ), the fyke nets are adapted to a depth of up to $8 \mathrm{~m} \mathrm{~m}$ and the traffic of recreational vessels. Relatively short (approximately $5 \mathrm{~m}$ long) fyke nets with round openings $1.5 \mathrm{~m}$ in diameter are used there (Fig. 3). At the fishing grounds located close to the Riga HPS (No. 8c), small lamprey fyke nets and lamprey trammel nets are used. Fyke nets are used during the periods of operation of the turbines at the Riga HPS, and their size and design is restricted by the high flow velocity. These fyke nets are up to $3 \mathrm{~m}$ long, $2 \mathrm{~m}$ wide and $1.5 \mathrm{~m}$ high with a round or half-round opening and without wings. Lamprey trammel nets are used in periods when the

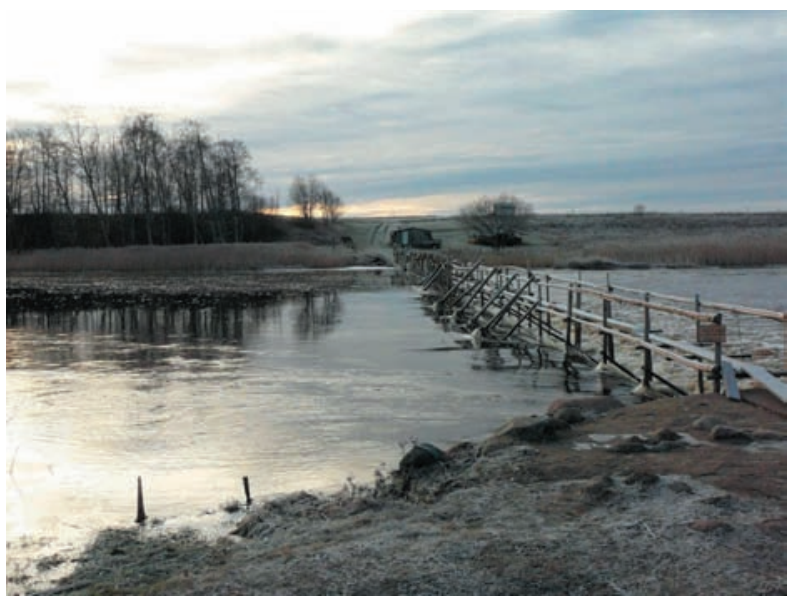

Figure 4. Lamprey weir on the Salaca River (fishing ground No. 8c). 
Riga HPS is accumulating water and the flow velocity is low. Lamprey trammel nets are 75 or $150 \mathrm{~m}$ long and $1.2 \mathrm{~m}$ high (mesh size $8-14 \mathrm{~mm}$ from knot to knot).

Lamprey weirs are operated only at shallow fishing grounds with a hard bottom substrate and a relatively high current velocity. Such fishing grounds are located on the Salaca (Nos. 1a, 1b, and 1c) and Svêtupe (No. 2) rivers and at the upper (No. 14d) fishing ground on the Venta River. Lamprey weirs in the Salaca and Svētupe rivers are complicated wooden structures that cross the entire riverbed (Fig. 4). There are two types of lamprey weir. In the first type, the openings of the fyke nets in a weir are oriented downstream and the lampreys are caught when ascending, i.e., migrating lampreys swim directly into the fyke net. This type of weir is currently being used at the lowest fishing ground (No. 1a) on the Salaca River. Lamprey weirs of the second type are made with the purpose of increasing the current speed and water level above the weir and modifying the flow of water. The structure of such weirs consists of a wooden beam fixed to the riverbed, a line of shields with slots between them, and a small (usually $45 \times 45 \mathrm{~cm}$ ) fyke net below each slot. In this type of lamprey weir, the fyke nets are set with their opening against the direction of the flow (Fig. 5) and the lampreys are caught when descending. By trying to overcome the shields, the lampreys swim into the section of very strong current between the shields and are pushed into the fyke net. The design of the lamprey weirs on the River Venta is much simpler and includes only the beam, metal plates, and fyke nets

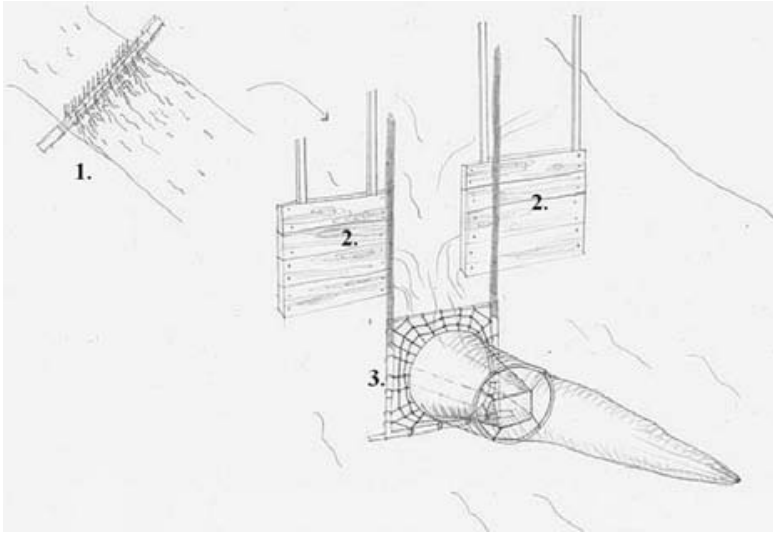

Figure 5. Basic information on the design of the lamprey weir where lampreys are caught descending. 1 - total view; 2 - shields; 3 - small fyke net.

attached to the dolomite riverbed by metal poles. The length of the lamprey weirs on the Venta River does not exceed $10-20 \mathrm{~m}$.

\section{Fishing procedures}

At most of the fishing grounds with a gear limit of three or more fyke nets, the fyke nets are used jointly. In most cases, fyke nets are set close to each other in one or several rows, perpendicular to the riverbank. The exception is the round, wingless fyke nets in the Daugava River (fishing ground 8b). These fyke nets are anchored in rows, parallel to the riverbank. The number of fyke nets in one row is limited by the pressure of the flow and does not exceed 8 to 10 .

The fishing gear is usually set in the evening and retrieved the next morning. This applies to all lamprey weirs, lamprey trammel nets, and the majority of

Table 3

Most successful fishing months at different fishing grounds

\begin{tabular}{ll}
\hline \hline Month & River (fishing ground) \\
\hline \hline September & Venta 14a, Venta (14c), Venta (14d) \\
October & Salaca (1a), Salaca (1b), Salaca (1c), Venta (14a), Venta (14b), Venta (14c), Venta (14d), Užava (15) \\
& Salaca (1a), Salaca (1b), Salaca (1c), Svētupe (2), Ağe (4), Pēterupe (6), Daugava (8a), Daugava (8b), \\
November & Daugava (8c), Grīva (9), Roja (10), Irbe (13), Venta (14a), Venta (14d), Užava (15), Saka (17) \\
December & Salaca (1a), Salaca (1b), Salaca (1c), Svētupe (2), Ağe (4), Daugva (8c), Grīva (9), Irbe (13) \\
April & Daugava (8c) \\
\hline \hline
\end{tabular}


lamprey fyke nets. When catches are high in volume, the fyke nets in lamprey weirs can be emptied several times in one night. At the lower fishing grounds on the Venta and Daugava rivers (Nos. 14a and 14b; 8a and $8 \mathrm{~b}$ ) and at the fishing grounds on the Saka, Gauja, Melnsilupe, Pilsupe, and Roja rivers, the fyke nets are set for a longer period (from several days up to a whole fishing season). The frequency of emptying of these fyke nets is different. The fyke nets on the Roja River are emptied daily. The fyke nets on the Venta and Pilsupe rivers and the fyke nets with wings on the Daugava River (fishing ground No. 8a) are emptied approximately once per week. The round wingless fyke nets on the Daugava River (fishing ground No. $8 b$ ) are emptied only a few times in the fishing season and are also used as storage for live lamprey.

\section{Factors determining the size of the catch}

There are three important groups of environmental factors that determine the size of the catch. The first group is related to wind. Wind direction is recognized as the most important factor at 21 fishing grounds, and catches increase with onshore winds and decrease with offshore winds. On the Roja and Saka rivers, the catch can also increase shortly after a change from onshore to offshore winds. At seven fishing grounds it was noted that the impact of wind increased with increased wind speed. The importance of the wind decreases with an increase in distance from the sea. At the fishing grounds on the Venta River located 11 and $16 \mathrm{~km}$ from the sea (Nos. $14 \mathrm{a}$ and $14 \mathrm{~b}$ ), the influence of the wind is less critical and is delayed for several days. At the fishing grounds located 20 and more $\mathrm{km}$ from the sea (the upper fishing grounds on the Venta and Daugava rivers (Nos. 14c, 14d and 8c), the wind is not noted to be an important factor.

The second group includes hydrological factors water level, flow velocity, and water quality. At all 24 fishing grounds, it is noted that the size of the catch increased together with increased water level and flow velocity. A less important factor is water quality.
At eight fishing grounds, increased catches are noted when the water is "fresh" (turbid water shortly after rain). At five fishing grounds, decreases are noted when the water is "bitter" or "marsh" (clear water with fallen alder leaves).

The third group includes factors relating to light conditions. All the fishers interviewed noted that light has a negative effect on catch size. Migration ceases during the day; however, the size of the catch is also affected by the lunar phase. At 12 fishing grounds, increased catches are detected during "dark moons" (waning crescent, new moon, and waxing crescent). At 18 fishing grounds, decreased catches are noted during full moons. However, the effect of the lunar phase is estimated to be less significant than the effects related to wind and water.

The size of the catch also depended on season. The biggest lamprey catches are usually obtained in the fall and at the beginning of winter (Table 3). At the upper fishing ground on the Daugava River (No. 8c), good catches are also obtained in April. At the fishing grounds on the Vitrupe, Pilsupe, Melnsilupe, and Riva rivers, the fishers interviewed were not able to estimate the best fishing period. Still, the catch size in particular seasons can also be affected by fishing opportunities. Lamprey fishing is often interrupted by the occurrence of meteorological factors such as flooding, the formation of ice sludge, etc., which are not suitable conditions for fishing. Such gaps in the fishing season can last from some days to several weeks. On the Saka River, the upper fishing grounds on the Venta River (Nos. 14c and 14d), and on the Daugava River, lamprey fishing depended on the rise of water levels and often commences only one to two months after the end of the closed season.

\section{Management}

At present, the river lamprey fishery in Latvia is strictly regulated. The location of the fishing grounds, the gear limit at each fishing ground, the length of the closed season, and the basic principles of the design and use of fishing gear are prescribed by legislation. The maximum width of the single fyke net is limited 
to $4 \mathrm{~m}$. The blocking of more than one half of the riverbed by a single fyke net, the wings of the fyke net, or the line of several fyke nets is prohibited. In lamprey weirs, at least one third of the riverbed must be left as free flow. The length of the fishing season in individual rivers is different. The shortest closed season (from May 1 to July 31) is for the Daugava River. On the Salaca, Svētupe, Gauja, Užava, Venta, Saka, and Irbe rivers, the closed season is from February 1 to July 31 . On all other rivers, the closed season is from February 1 to October 31. Recreational fishing for river lamprey is forbidden in Latvia. The river lamprey fishing gear limit can be distributed only among individual fishers or fishing enterprises licensed for commercial fishery. Licenses for inland fisheries are issued by local municipalities, to which the distribution of the lamprey fishing rights is also delegated. The limits on fishing gear are distributed based on contracts for the lease of fishing rights between municipalities and fishers or fishing enterprises. The duration of these contracts is from three to 15 years. However, fishing licenses are issued annually by the State Environmental Service. In 2012, lamprey fishing licenses were allocated to 86 individual commercial fishers and fishing enterprises. Fishing gear limits at a particular fishing ground are frequently leased to several fishers or fishing enterprises. This also applies to fishing grounds where fishing gear are used jointly.

Catch statistics data was collected from logbooks that contain information on the type and number of the fishing gear and the size of the catch. Fishers are obliged to fill in logbooks after each fishing session. Logbooks are issued and collected monthly by the State Environmental Service. Logbook data is compiled and digitized at the BIOR Institute.

\section{Discussion}

The lamprey fishing effort and catch size in Latvia in the last few decades was stable. The only changes in fishing effort were noted in the opening or closing of a few fishing grounds with minor (less than $0.5 \mathrm{t}$ ) annual catches. The low intensity of opening new fishing grounds can be explained by lamprey resources conservation issues (in rivers with previously existing fishing grounds) or by the lack of lamprey fishing tradition and the low catch expected in other rivers. Greater changes can be observed over the longer period; during the 1960 s, the lamprey fishing effort was concentrated on the Gauja River, and the share from this river usually exceeded $50 \%$ of the total annual catch (Ryapolova 1968). The historical gear limit in this river (400 fyke nets and one additional lamprey weir) was also much higher than currently at (Ryapolova 1972). According to Zilvere (2009), the historical fishing gear limit was also higher on the Salaca River. In addition, the length of the fishing season is currently shorter than that during the 1960s and 1970s, when the beginning of the closed season was on April 15. The importance of fishing during the spring is confirmed by fishers in Daugava River who indicated that April is a successful fishing month. The spring migration peak for river lamprey in Latvia is also mentioned in previous research (Abakumov 1956, Eglìte 1961). It is obvious that, in spite of the opening of new fishing grounds on several small rivers, the overall fishing effort is much smaller at present than it was in the 1960s and 1970s.

Other significant long-term change concerns the type of lamprey fishing gear. Historically, the most widely used type of fishing gear was the lamprey weir. In the 1960s, the use of lamprey weirs was mentioned on the Gauja (Abakumov 1956) and Daugava rivers (Ryapolova 1972). Increase of the fyke net use began in the middle of the 1960s (Ryapolova 1968). Currently, lamprey weirs at the majority of fishing grounds have been completely replaced by lamprey fyke nets, and the increased use of fyke nets has also been registered in Finland (Sjöberg 2013). The fishing gear in the Daugava River has evolved to meet changes caused by the construction and operation of the Riga HPS and the development of the city of Riga and the Freeport of Riga.

The decrease in the fishing effort and the change in the type of fishing gear raises the question of the extent to which annual catch dynamics can be used 
to evaluate the long-term dynamics of river lamprey resources. On the other hand, it has to be taken into account that catch statistics are the only accessible long-term data. In future, the use of long-term catch data can be improved by evaluations of recent fish mortality and measuring it against the results of previous research (Abakumov 1956, Ryapolova 1970).

Also at a relatively stable gear limit, catch size might not correspond to the actual size of the lamprey population. The size of the catch is greatly affected by fishing opportunities and the intensity of lamprey migration during the fishing season. The most important non-resources related factors which determine the intensity of the migration and size of the catch (lunar phase, wind direction, and flow velocity) indicated in this research corresponds with the results of research done during the 1960s and 1970s (Eglīte 1961, Ryapolova 1964, 1972, Evtjuhova and Ryapolova 1967).

However, previously it was agreed that non-resources related factors can only have a short-term impact and the total size of the annual catch is determined mostly by the year-class strength (Eglite 1961, 1975, Ryapolova 1962). The results of this research permit the presumption that considering the shortened lamprey fishing season in most rivers, the non-resources related factors are more important than they have previously been estimated to be. The high importance of non-resources related factors is also illustrated by the fishing results in 2012. During December of that year, lamprey fishing almost completely ceased because of unsuitable meteorological conditions. As a result, the total size of the annual catch in 2012 was below the average, despite the high catches during October and November.

In further research, a simple comparison of the total annual catch size should be avoided. The current catch data collection system in Latvia provides highly detailed catch data. It opens up grounds for further research into the role of different environmental factors and interpretations of the catch statistics data. For a simplified improvement in the future use of catch data, the use of the catch in November only is suggested. November is considered to be an important lamprey fishing month at almost all fishing grounds, and lamprey fishing during November is usually not interrupted by meteorological factors.

The fact that the influence of wind direction decreases with an increase in the distance from the sea should be noted. This supports the opinion that the effect of wind direction on lamprey migration is realized through a change of freshwater discharge. According to Ryapolova $(1964,1972)$ and Evtuhova and Ryapolova (1967), onshore winds cause freshwater accumulation in estuaries and leads to increases in freshwater discharge after a change in the wind direction. The results of this research also confirm the hypothesis of the possible role played by the operation of the Riga HPS on the occurrence of river lamprey in Daugava River (Birzaks and Abersons 2011). It is very likely that the artificial increase in freshwater discharge during periods of turbine operation at the Riga HPS attracts migrating lamprey to the Daugava River, which is not their spawning river. Fishers interviewed during this research did not point out that such anthropogenic factors as river damming or pollution had significant impacts on the sizes of the catches. No new dams have been built in recent decades in rivers that are important for anadromous fish migration in Latvia. The low importance of pollution can partly be explained by the reduction of agricultural and industrial pollution and the improvement of water quality after the collapse of the Soviet Union in 1991 (Juhna and Klavins 2001), and by efforts made to implement the Water Framework Directive requirements in recent years. It must also be taken into account that changes in catch reflect mostly distinct, short-term changes, but fishers might not notice long-term trends. One such trend is the "brownification" of Latvian rivers, i.e., increases of total organic carbon and water color values (Klavins et al. 2011). The size of the catch can also be influenced by natural or human-induced changes in the ecosystem of the Baltic Sea, like increases in the cod, Gadus morhua L., stock in the past (Birzaks and Abersons 2011) or the current expansion of the round goby, Neogobius melanostomus (Pallas) (Kornis et al. 2012).

In the long-term, the scale of lamprey fishing can also be influenced by changes in the market. 
Lamprey fishing is not the only source of income for most lamprey fishers, and fishing for other species or having an occupation not related to fisheries is most likely linked with the relatively short lamprey fishing season and the limited fishing effort rather than with the situation in the market. None of the fishers interviewed during this research mentioned problems with selling lampreys. The high demand and price for lampreys in Latvia is also pointed out by Sjöberg (2011). Sjöberg (2013) also indicates the importance of the tradition of lamprey fishing even if the economic importance of lamprey is decreasing. Changes in the river lamprey market are not anticipated to result in a significant reduction of lamprey fishery in Latvia in the coming decades.

For a better understanding of the status of the lamprey population, other data sources must be used as well. One such source is the monitoring of river lamprey ammocoetes. Improvement in monitoring ammocoetes will also permit evaluating the utility of the lamprey restocking program, which is a part of the National Fish Resources Restocking Program. The annual quantity of stocked river lamprey ammocoetes since 2004 has ranged from 7.2 to 16.3 million (Anonymous 2013).

Acknowledgments. The authors would like to thank all of the fishers interviewed for their cooperation. We are also grateful to our colleagues Jānis Aizups and Ëriks Aleksejevs for sharing the catch statistics data, and our colleague Māris Strūğis and our friend Ieva Putninga for help with the illustrations. This research was financed by the Institute of Food Safety, Animal Health, and Environment BIOR.

Author contributions. K.A. and J.B. wrote the paper, K.A. performed the catch data analysis and interviewed the fishers.

\section{References}

Anonymous 2013 - Number of larvae and young fish produced by State fish hatcheries and released to natural waters - In: Latvian Fisheries yearbook 2009, Latvijas lauku konsultâciju un izglīî̄bas centrs, Rīga: 145-146.
Abakumov V.A. 1956 - On the life history of the river lamprey from the Baltic Sea - Vopr. Ikhtiol. 6: 122-128 (in Russian).

Bartel R., Bradauskas B., Ikonen E., Mitans A., Borowski W., Garbacik-Wesołowska A., Witkowski A., Błachuta J., Morzuch J., Bernaś R., Kapusta A. 2010 - Patterns of river lamprey size and sex ratio in the Baltic Sea basin Arch. Pol. Fish. 18: 247-255.

Birzaks J., Abersons K. 2011. - Anthropogenic influence on the dynamics of the river lamprey Lampetra fluviatilis landings in the River Daugava Basin - Scientific Journal of RTU. Environmental and Climate Technologies, 13/7: 32-38.

Birzaks J., Abersons K., Baranova T. 2011a - Long term dynamics of river lamprey fishery in Latvia - Book of abstracts, ICES Annual Science Conference 19-23.09. 2011, ICES, Gdansk: 128.

Birzaks J., Aleksejevs Ç., Strūğis M. 2011b - Occurrence and distribution of fish in rivers of Latvia - Proc. Latvian Acad. Sci. Section B 65 3/4: 20-30.

Eglīte R. 1961 - Migration and spawning of river lamprey Lampetra fluviatilis (L.) in the rivers of the Latvian SSR P. Stučkas Latvijas Valsts Universitātes Zinātniskie raksti 39: 9-28 (in Latvian).

Eglīte R. 1975 - Increase of river lamprey Lampetra fluviatilis (L.) catch in the rivers of Latvian SSR - Zoologijas muzeja raksti 12: 99-104 (in Latvian).

Evtjuhova B., Ryapolova N. 1967 - The impact of hydrometeorological factors on the dynamics of spawning migration of Atlantic salmon and river lamprey - In: Rybohozjaistvennye issledovanija v bassejne Baltijskogo morja, Zvajgzne, Riga 2: 53-65 (in Russian).

Juhna T., Klavins M. 2001 - Water-quality changes in Latvia and Riga 1980-2000: possibilities and problems - Ambio 30: 306-314.

Kelly F.L., King J.J. 2001 - A review of the ecology and distribution of three Lamprey species, Lampetra fluviatilis (L.), Lampetra planeri (Bloch) and Petromyzon marinus (L.): a context for conservation and biodiversity considerations in Ireland - Proc. R. Irish. Acad. 101B (3): 165-185.

Kļaviņš M., Kokorīte I., Radinovs V. 2011 - Dissolved organic matter concentration changes in river waters of Latvia Proc. Latvian Acad. Sci. Section B 1/2: 40-47.

Kornis M.S., Mercado-Silva N., Vander Zanden M.J. 2012 Twenty years of invasion: a review of round goby Neogobius melanostomus biology, spread and ecological implications - J. Fish Biol. 80: 235-285.

Maitland P.S. 1980 - Review of the ecology of lampreys in northern Europe - Can. J. Fish. Aquat. Sci. 37: 1974-1980.

Maitland P.S. 2003 - Ecology of the River, Brook and Sea Lamprey Lampetra fluviatilis, Lampetra planeri and 
Petromyzon marinus - Conserving Natura 2000 Rivers Ecology Series No. 5. English Nature, Peterborough.

Masters J. E. G., Jang M.H., Ha K., Bird P.D., Frear P.A., Lucas M.C. 2006 - The commercial exploitation of a protected anadromous species, the river lamprey (Lampetra fluviatilis (L.)), in the tidal River Ouse, north-east England - Aquat. Conserv. 16: 77-92.

Ryapolova N. 1962 - Some Data on the condition of stock of river lamprey Lampetra fluviatilis (Linné) in the rivers of the Latvian SSR - In: Trudy konferencii molodyh specialistov, Izdatel'stvo Akademii Nauk Latvijskoi SSR, Riga: 73-81 (in Russian).

Ryapolova N. 1964 - About the Consequences of spawning migration of River Lamprey Lampetra fluviatilis L. in the Rivers of the Latvian SSR - In: Trudy molodyh uchonyh, Pishhevaja promyshlennost', Moscow: 66-69 (in Russian).

Ryapolova N. 1968 - The possibilities of Latvian river lamprey stock and catch prediction - In: Rybohozjaistvennye issledovanija $\mathrm{v}$ bassejne Baltijskogo morja, Zvajgzne, Riga 4: 199-215 (in Russian).

Ryapolova N. 1970 - Results of tagging of river Lamprey (Lampetra fluviatilis L.) in the Gauja River - In: Trudi Baltijskogo Nauchno-Isledovatel'skogo instituta Ryb- nogo Hozjajstva (BaltNIIRH). Zvajgzne, Riga, 4:379-389 (in Russian).

Ryapolova N. 1972 - River Lamprey in the eastern Baltic Zinatne, Riga: 43 (in Russian).

Sjöberg K. 1982 - Exploitation of Lampreys in Europe Ethnol. Scand. 1982: 94-108.

Sjöberg K. 2011 - River lamprey Lampetra fluviatilis (L.) fishing in the area around the Baltic Sea - J. North. Stud. 5: 51-86.

Sjöberg K. 2013 - Fishing gear used for river lamprey Lampetra fluviatilis (L.) catches. Documenting rivers that flow into the Baltic Sea. Part II, Finland, Latvia and Estonia - J. North. Stud. 7 7-74

Thiel R., Winkler H.M., Riel P., Neumann R., Grohsler T., Bottcher U., Spratte S., Hartmann U. 2009 - Endangered anadromous lampreys in the southern Baltic Sea. Spatial distribution, long-term trend, population status Endang. Species Res. 8: 233-247.

Tuunainen P.E., Ikonen E., Auvinen H. 1980 - Lampreys and lamprey fisheries in Finland - Can. J. Fish. Aquat. Sci. 37: 1953-1959.

Zilvere I. 2009 - The history and tradition on lamprey fishing in Salaca River - In: Latvian Fisheries yearbook 2009, Zivsaimniecības informācijas birojs, Rīga: 144-152 (in Latvian). 